\title{
Implementation of E-leaning in Indonesian Language Subject
}

\author{
Widia Nopita Sari \\ State Islamic Intitute of Bengkulu \\ widianopitasari99@gmail.com \\ Kasmantoni \\ State Islamic Intitute of Bengkulu \\ kasmantoni1975@gmail.com \\ Hengki Satrisno \\ State Islamic Intitute of Bengkulu \\ hengkidalima@gmail.com
}

\begin{abstract}
The purpose of this study was to determine the implementation of e-learning in Indonesian class XI IBB subjects at SMAN 04 Bengkulu City. This study used qualitative research methods. Data collection techniques using observation, interviews and documentation. Data analysis techniques are data reduction, data presentation and drawing conclusions and verification. The informants in this study were the Indonesian language teacher and three students of class XI IBB. The implementation of this research began on May 06 to May 31, 2021. The results of this study were the implementation of E-learning in Indonesian Class XI IBB subjects at SMAN 04 Bengkulu City was very good and complete. Starting from the homepage, absences, announcements, messages, teaching schedules, related links, assignments, materials, my comments, achievement of basic competencies, group assignments, teacher filters, student filters and logout or exit. The implementation of elearning makes it very easy for teachers to continue teaching and also greatly facilitates students in learning. While the obstacles to implementing e-learning in Indonesian class XI IBB subjects at SMAN 04 Bengkulu City are infrastructure, cellphones, quotas, difficult signals, servers that sometimes have errors and lack of notifications.
\end{abstract}

Keywords: E-learning, Indonesian Language Education.

\section{A. Introduction}

The emergence of Covid-19 is quite impactful to the world, since the virus appeared the world has been a bit chaotic, Covid-19 is dangerous virus that can cause death, the impact of pandemic to the world is not only in health but also in other aspects of life, such as economy, trading, education and others. Education is indeed only for human, because only human that can be educated.

Education plays an important role in preparing good human resources. Therefore, education is supposed to be properly managed both in its quality and quantity. There is 
learning in education. Learning is a process of teaching and learning that can be found in school. Teaching and learning are 2 inseparable concepts. Learning aims to what one has to do as a subject who receives the lesson, meanwhile teaching aims to what the teacher has to do as a tutor. The definition of learning can not be separated from the definition of studying, studying and leaning are inseparable series of activity. The result of learning becomes model in the next process of learning. Learning means learning activity done by teacher and students.

Along with the development of technology and information that get more developed and advanced, making teachers do not get too frustated to teach in this pandemic situation. As many learning models that can be implemented, for instance by using Whatsapp, Google Classroom, Zoom and E-learning. Form of development of technology and information applied in the field of education is e-learning. E-learning is an inovation that has profound contribution on the change of learning process. Form of development of technology and information applied in the field of education is e-learning. E-learning is an innovation that has profound contribution on the change of learning process.

E-learning has a lot of advantages for students, if managed well. For instance by making a learning process exciting, so that it makes students do not get bored easily, understand the given lesson easily, and have eagerness to keep following the learning process. Then the advantage of e-learning is so efficient and practice and make students more sensitive with the advance of technology. The advantage of e-learning is that it does not spend internet quota too much unlike Zoom and Whatsapp that must use voice note and video, although e-learning does not spend internet quota too much, but sometimes there are still students who are left behind in learning process with an excuse of not having internet quota and good signal. Besides, the advantage of e-learning is an easy learning model, elearning can be done anywhere and anytime. And flexible learning time.

\section{B. Research Method}

This is a qualitative research. Qualtitative research method is a research method that is based on postpositivism philosophy, used to reseach natural object, then qualitative reseach is a research that produce descriptive data in form of written or spoken words from the investigated subjects or objects. 
The reseach to be carried out uses descriptive qualitative approach to describe and interpret about condition or relation, grown opinion, on going process, cause or effect happening, or developing tendency, thus descriptive reseach is used. Descriptive reseach is called non hypothetical research.

So, descriptive research is a reseach to produce descriptive data in form of words from investigated people and behaviour that can be observed and also interpreted appropriately.

The location of this research will be done at SMAN 04 Bengkulu City academic year 2021, began on May 06 to May 31. The subject of this research is resource where data is gained. The subject of this research is informant who will give data about the research to be carried out and investigated by researcher consisting of principal, Indonesian language teachers, peer teachers, and 3 students of class XI IBB SMAN 04 Bengkulu City. The used data collection technique in collecting data in this research were observation, interview, and documentation. The data validity technique used by researcher were data triangulation, technique triangulation, and source triangulation. Data analysis technique used by researcher were data reduction, data presentation, drawing conclusion, and verification.

\section{Result and Discussion}

\section{Result}

Result of research about implementation of e-learning in Indonesian Language subject at class XI IBB at SMAN 04 Bengkulu City done with obsevation and interview is as follow.

Based on the observation result by observing Mrs. Hermis Paris as Indonesian language teacher at class XI IBB at SMAN 4 Bengkulu City obtained data that implementation of elearning in Indonesian language subject at class XI IBB at SMAN 04 Bengkulu City was quite good, teachers did learning as learning schedule, teachers did not get difficulty too much in operating e-learning, students' response was also quite good, quite understandable material delivery, the teachers and the students were still active despite online learning.

Based on observation result by observing a student named Naila Zulvia the obtained data that students were ready to open e-learning when the class is about to start, students were always ready as well to see instruction from teacher, both material or task, students did not seem to get too much difficulty in using e-learning, however they got a bit trouble in signal that slowed down e-learning. 
Based on interview result with Mrs. Hermis Paris S.Pd as Indonesian language teacher at class XI IBB at SMAN 4 Bengkulu City

1. How is the planning of e-learning in Indonesian language subject at class XI IBB at SMAN 4 Bengkulu City?

"The planning of e-learning implementation in Indonesian language subject at class $\mathrm{XI}$ IBB at SMAN 4 Bengkulu City is started from the school that has agreed to use e-learning as online learning media, in the planning of its implementation has got support dan separate policy from the school. So the teachers and students just follow the school".

2. How is the implementation of e-learning in Indonesian language subject at class XI IBB at SMAN 4 Bengkulu City?

"The implementation of e-learning in Indonesian language subject at class XI IBB at SMAN 4 Bengkulu City was in the end of academic year 2020/2021. The implementation of e-learning was excellent, the teachers have done learning well, meanwhile the students have also responded learning well already."

3. How is the evaluation of e-learning in Indonesian language subject at class XI IBB at SMAN 4 Bengkulu City?

"The evaluation of e-learning in Indonesian language subject at class XI IBB at SMAN 4 Bengkulu City have no particular evaluation system yet toward learning”.

4. How is the process of learning and teaching from opening activity, main activity, and closing activity in e-learning in Indonesian language subject at class XI IBB at SMAN 4 Bengkulu City?

"In opening activity the teachers asked students to open e-learning and required students to check task given. In main activity the teachers asked students to observe and learn the task given, if students did not understand, they may ask queations in the comment section, if students had understood they would no longer ask but learned and did the task right away. In closing activity the teachers told students to do task according to the time given".

5. What are the positive and negative impacts of e-learning implementation in Indonesian language subject at class XI IBB at SMAN 4 Bengkulu City?

"The positive impact of e-learning implementation in Indonesian language subject at class XI IBB at SMAN 4 Bengkulu City could save cost, make learning easy because 
students can learn from various sources not only from books but also with internet and the last students can think more creatively because they can learn with various unique and attractive learning such as through videos on youtube. Meanwhile, for the negative impacts students may find it a bit difficult to understand some learning materials that is supposed to be done directly and real, for instance speech material, in speech material students should practice preaching but because the learning is done online that it makes learning material less effective."

6. How is the implementation of e-learning in Indonesian language subject at class XI IBB at SMAN 4 Bengkulu City?

Based on interview result with Mrs. Hermis Paris, S.Pd as Indonesian language teacher at class XI IBB at SMAN 4 Bengkulu City

"E-learning implementation in Indonesian language subject at class XI IBB at SMAN 4 Bengkulu City was quite good and complete, starting from link given by the school, after that going to e-learning website of SMAN 4 Bengkulu City, after entering the website the homepage consists of login e-learning in which there are username and password then there are additional symbol online material, online task, online examination, and online assessment. If we have logged in to e-learning the menu will be more complete consisting of homepage, announcements, messages, teaching schedule, related link, task, material, my comment, achievement of basic competence, group task, teacher filter, student filter, and logout or exit. E-learning is equipped with absence, delivery of material, assignment submission, there are non physical and physical assignments, the non physical ones is submitted through e-learning, meanwhile physical one is submitted directly to the teachers concerned. And the impelementation of e-learning at Indonesian language subject at class XI IBB was also excellent, teachers had been so good at delivering material and also assigments, students also had been able and easily understood materials given by the teachers. The following were some materials of Indonesian language subject during elearning. Some materials of Indonesian language subject learned through e-learning were analyzing language review, scientific work material, speech material, explanation text and procedure text material. Teachers also always warned and informed their students to always hand in assigments and examinations through e-learning. The implementation of e-learning in Indonesian language subject at class XI IBB at SMAN 4 Bengkulu City was not so different 
between e-learning and face to face learning process, what differs them is only if face to face learning process teacher and students interact directly but if in e-learning teacher and students interact through electronic media such as phone and laptop".

Based on interview result with a peer teacher Mrs. Dwi Rahma Aprilia

"It has been so good, e-learning is so complete and it helps teachers a lot to conduct learning even though through online learning."

Based on interview result with a student named Naila Zulvia

"It has been so good and complete, because e-learning has been so complete, starting from list of attendees, giving material, giving assigment, and task submission. Material of Indonesian language given by teacher in e-learning is also quite easy to be understood and learned, it is not too hard or difficult for students, so that students are happy and active in learning".

Based on interview result with a student named Deny Ilham

"The implementation has been quite good and complete, starting from list of attendees, giving assignment, and others have been available in e-learning. E-learning in Indonesian language subject is also quite easy to be learned, materials given by teacher is not too difficult and not too boring, because there are some other materials that are quite difficult to be learned and also boring".

Based on interview result with a student named Deny Ilham

"The implementation is good and complete, strarting from list of attendees until assignment have been available in e-learning, and material of Indonesian language subject given by teacher do not get students confused, the material is quite easy."

7. What are the obstacles in the implementation of e-learning in Indonesian language subject at class XI IBB at SMAN 4 Bengkulu City?

Based on interview result with Mrs. Hermis Paris, S.Pd as Indonesian subject teacher at class XI IBB at SMAN 4 Bengkulu City

"The obstacle was in facility and infrastucture such as phone, because not all students have good economy, there are some students whose economy is not so good. The second was signal, signal is still also a problem because we do not know what will happen while learning in e-learning, sometimes when learning the electricity went out, it might affect the signal as well. The third is internet quota, it is also a problem for students, similarly with phone, 
internet quota also depends on family's economy from students, if the students are less privilaged, so they are not able to keep buying internet quota. The fourth is laziness, and the fifth is made up excuses such as forgetting, not knowing, and not remembering."

Based on interview result with a peer teacher Mrs. Dwi Rahma Aprilia

"The obstacle is in facility and infrastructure, phone, internet quota and signal. Many students do not have phone because of unability to buy, unable to keep buying internet quota because of mediocre economy and unstable signal. The obstacles above can affect e-learning process in Indonesian subject at class XI IBB at SMAN 4 Bengkulu City. With obstacles as what I mentioned before make learning process not objective."

Based on interview result with a student named Naila Zulvia

"The obstacle was not having internet quota and shortage of internet quota, because not all people are able to buy internet quota. The signal was difficult, for example if the electricity is going out the signal will be so difficult to get, sometimes it dissappeared or no signal at all. Boring learning, too many assigments, so that there are often deadlines. Elearning website was sometimes error, lack of facility and infrastructure such as phone becuase not all students have phone, there are still many students who are not able to buy phone, there are also students whose phone is broken or get confiscated. Besides, for students who do not have phone, they are required to come to school everyday to fill in absentee. And lack of notification, if there are assignments but there is no notification from e-learning".

Based on interview result with a student named Deny Ilham

"The obstacle is not having internet quota and shortage of internet quota, because not all people are able to buy internet quota. The signal is difficult, for example if the electricity is going out the signal will be so difficult to get, sometimes it dissappeared or no signal at all. Boring learning, too many assigments, so that there were often deadlines. E-learning website is sometimes error, lack of facility and infrastructure such as phone becuase not all students have phone, there are still many students who are not able to buy phone, there are also students whose phone is broken or get confiscated. Besides, for students who do not have phone, they are required to come to school everyday to fill in absentee. And lack of notification, if there were assignments but there is no notification from e-learning".

Based on interview result with a student named Ratna Pratiwi 
"The obstacle was phone and internet quota, because some students do not have phone and there are some students who are not able to buy internet quota either, and lack of notification".

Based on interview result with the pricipal of SMAN 4 Bengkulu City

8. Have the planning, implementation, and evaluation of e-learning in Indonesian subject at class XII IBB at SMAN 4 Bengkulu City been good and right?

"Yes, it has been done well, it has been done with well-planned preparation, the implementation has been done and the evaluation is done in every new academic year."

9. Has Mrs. Hermis applied e-learning well in Indonesian subject at class XI IBB at SMAN 4 Bengkulu City?

Based on interview result with the principal of SMAN 4 Bengkulu City

"Yes, it has been implemented well".

Based on interview with a peer teacher Mrs. Dwi Rama Apriliani S.Pd

"Yes, it has been implemented well".

10. Are you happy with e-learning?

Based on interview result with a student named Naila Zulvia

"Yes, I am happy".

Based on interview result with a student named Deny Ilham

"Yes, I am happy".

Based on interview result with a student named Ratna Pertiwi

"Yes, I am happy".

\section{Discussion}

Based on result of research done by researcher about implementation of e-learning in Indonesian subject at class XI IBB at SMAN 4 Bengkulu City there is a discussion that will be discussed in this research.

Implementation means application or execution. It means which is implemented and applied is curriculum that has been arranged and designed to be fully implemented. Implementation is an action or application of a detailed well-thought-out plan. Implementation can be defined as application or operationalization of an activity in order to achieve a target or goal. (Firdianti, 2018). E-leaning is a distance learning process by 
combining principles in technology learning process. (Chandrawati, 2010). E-learning is teaching and learning activity that use internet. (Asep, 2005).

E-learning implementation planning in Indonesian subject at XI IBB class follows plan from the school, if implementation planning from school has been implemented so e-learning implementation in Indonesian subject is also implemented with school. Initally, e-learning was implemented because of the difficulty of online learning caused by Covid-19 and finally school initated to conduct learning from home through e-learning, e-learning helped teachers so much in doing their obligation as a teacher. E-learning also provided easiness for the teachers in teaching as e-learning is easy and simple enough to be operated. The implementation was done when school had consented the use of e-learning as a learning media at SMAN 4 Bengkulu City, the impelentation was done in the end of semester academic year 2020/2021. Evaluation of e-learning implementation in Indonesian subject is not that much and there is not special evaluation yet, even though there is not special evaluation yet to every subject, the school always do evaluation and also keep improving the qualtity of e-learning in every new academic year.

Teaching and learning activity using e-learning in Indonesian subject at class XI IBB was quite effective despite online learning, the teaching and learning activity is almost similar with face to face learning activity. Teaching and learning activity was started from opening activity, main activity, and closing activity. What differs the two is in opening and closing of e-learning that is not much.

The positive and negative impcats of e-learning implementation in Indonesian subject at class XI IBB, the positive impact is students can save cost, started from transportation cost, shopping cost, and other necessities. Making learning easier with creative, unique, and modern sources. The negative impact is students may find it a bit difficult to understand material that is supposed to be done directly but it is done online, because no matter how sophisticated online learning is, it will be more effective if learning is done directly.

Implementation of e-learning on Indonesian language subject at class XI IBB at SMAN 04 Bengkulu City was quite good and complete, starting from list of absentee, annoucement, giving material, giving assigment, and task submission. The teachers and students no longer need to bother, because learning is only done in one application. Teachers and students do not need to bother because e-learning can be opened anywhere and anytime. Teachers and 
students do not find it too difficult to give and accept assigments that are given. The materials given are also quite easy and simple for example procedure text. But there are some materials that are hard to be understood online, that kind of material need to be done directly such as speech material.

Obstacles of e-learning implementation in Indonesian subject at class XI IBB is not too much, students only got obstacle in facility and infrastructure, but school have prepared facility for students who do not have facility and infrastructure. Internet quota and signal, maybe there are some students who are less in term of economy, meanwhile signal will also dissapear if the electricity goes out.

Implementation of e-learning on Indonesian language subject at class XI IBB at SMAN 04 Bengkulu City was quite good and complete, starting from list of absentee, annoucement, giving material, giving assigment, and task submission. The teachers and students no longer need to bother, because learning is only done in one application. Teachers and students do not need to bother because e-learning can be opened anywhere and anytime. Teachers and students do not find it too difficult to give and accept assigments that are given. The materials given are also quite easy and simple for example procedure text. But there are some materials that are hard to be understood online, that kind of material need to be done directly such as speech material.

Obstacles of e-learning implementation in Indonesian subject at class XI IBB is not too much, students only got obstacle in facility and infrastructure, but the school have prepared facility for students who do not have facility and infrastructure. Internet quota and signal, maybe there are some students who are less in term of economy, meanwhile signal will also dissapear if the electricity goes out.

\section{Conclusion}

Based on the result of research done at class XI IBB at SMAN 4 Bengkulu City, the implementation of e-learning on Indonesian Language subject was quite good and complete. Starting from list of absentee of teachers or students, until task submission are available in one application. Even though there are some assigments that have to be handed in directly at school. Obstacles of facility and infrastructure such as phone, internet quota, error server, and lack of noticication. But school have prepared facility and infrastructure for instance 
providing computer laboratorium to students who do not have phone. Error server and lack of notification have also been fixed with the improvement of e-learning in every new academic year. During this pandemic, the teachers kept warning and informing their students to understand and gave assignments according to the given time.

\section{References}

Elyas, A.H. (2018). Penggunaan Model Pembelajaran E-learning dalam Meningkatkan Kualitas Pembelajaran.Jurnal Warta, 56(1), 23.

Yunianto, A.R. (2015). Implementasi E-learning Berbasis Kalase Sebagai Sumber Belajar (Studi Kasus Siswa Kelas X Jurusan Multimedia di SMK Bagimu Negerku Semarang). Semarang: Universitas Negeri Semarang.

Wijaya, D.P.W. (2015). Implementasi E-learning di SMPN 10 Yogyakarta. Skripsi. Yogyakarta: Universitas Negeri Yogyakarta.

Asmarani, D. (2019). Pengembanagan Media Pembelajaran Bahasa Indonesia SD/MI Berbasis Android. Skripsi. Lampung: Tarbiyah dan Keguruan UIN Raden Intan Lampung.

Hidayah, F. (2012). Penerapan E-learning sebagai Media Pembelajaran Mata Diklat Pemrograman WEB kelas XI Teknik Komputer Jaringan SMK N 2 Pengasih. Skripsi. Yogyakarta: Universitas Negeri Yogyakarta.

Rohmah, H.N. (2020). Efektivitas Penggunaan E-learning Dalam Pembelajaran Fiqih Untuk Meningkatkan Hasil Belajar Peserta Didik Kelas XI MAN 1 Tulungagung. Skripsi. Tulungagagung: IAIN Tulungagung.

Aflaha, N. (2015). Peningkatan Hasil Belajar Bahsa Indonesia Materi Cerita Pengalaman yang Mengesankan Melalui Metode Index Card Match pada Siswa Kelas III MI Sabilul Huda (SD Plus) Kalitangi Tahun Ajaran 2015/2016. Salatiga: IAIN Salatiga 
Tambunan, H. Model Pembelajaran Berbasis E-learning suatu Tawaran Pembelajaran Masa Kini dan Masa yang Akan Datang.

Haryanto. (2017). Kajian Implementasi Pembelajaran Berbasis E-learning dengan Pendekatan Unified Theory of Acceptance and Use of Technology (UTAUT) (Studi Kasus pada SMP Al-Amanah, Kota Tangerang Selatan) Jurnal Khatulistiwa Informatika, V(1), 24.

Yustianti, I., \& Novita, D. (2019). Pemanfaatan E-learning bagi Para Pendidik di Era Digital 4.0 Utilization Of E-learning for Educators in Digital Era 4.0. Prosiding Seminar Nasional Pendidikan Program Pascasarjana Univesitas PGRI Palembang.

Saddhono, K., \& St. Y, Slamet. (2012). Meningkatkan Keterampilan Berbahasa Indonesia (Teori dan Aplikasi). Bandung:Karya Putra Darwati.

Mahmud. (2011). Metode Penelitian Pendidikan. Bandung:Pustaka Setia.

Ramadhani, M. (2012). Efektivitas Penggunaan Media Pembelajaran E-learning Berbasis Web Pada Pelajaran Teknologi Informasi dan Komunikasi Terhadap Hasil Belajar Siswa Kelas X SMAN 1 Kalasan. Yogyakarta: Universitas Negeri Yogyakarta.

Yolandasari, M.B. (2020). Efektifitas Pembelajaran Daring Dalam Pembelajaran Bahasa Indonesia di Kelas II A MI Unggulan Miftahul Huda Tumang Cepogo Boyolali Tahun Pelajaran 2019/2020. Salatiga: IAIN Salatiga.

Hanafy, M.S. (2014). Konsep Belajar dan Pembelajaran. Jurnal Lentera Pendidikan, 17(1), 45. 